\title{
Primary breast lymphoma of childhood: a case report and review of literature
}

\author{
Giulia A. Restivo', Marta Pillon², Lara Mussolin",3, Clara Mosa4 , Angela Guarina4, Angela Trizzino4, \\ Salvatore laluna ${ }^{5}$, Elisa Carraro², Emanuele S.G. D'Amore ${ }^{6}$, Giovanna Russo ${ }^{7 *} \mathbb{D}$, Caterina Elia ${ }^{8}$, \\ Maurizio Mascarin ${ }^{8}$, Adriana Zangara ${ }^{9}$, Paolo D'Angelo ${ }^{4}$ and Piero Farruggia ${ }^{4}$
}

\begin{abstract}
Background: Primary breast lymphoma (PBL) is an extremely rare neoplasm in children; by definition, it manifests in the breast without evidence of lymphoma elsewhere, except ipsilateral axillary nodes.

Case presentation: We report a case of a 15-year-old girl diagnosed with diffuse large B-cell lymphoma (DLBCL) of the right breast: the patient received chemotherapy and rituximab, achieving complete remission. A literature review revealed other 11 cases of pediatric PBL; it mainly affects female adolescents and can involve right and left breast equally. Different histologic subtypes have been described, arising from both B-cell and T-cell. Therapeutic approaches were very different, from chemotherapy to local treatment with surgery and/or radiotherapy.

Conclusions: Our case is the first in which rituximab was administered, suggesting to be a promising therapy in B-cell PBL, as already demonstrated in pediatric B-cell lymphoma from other sites. Further investigations are needed to identify prognostic factors and establish the most effective treatment.
\end{abstract}

Keywords: Primary breast lymphoma, rituximab, Children

\section{Background}

Breast malignancy is a rare disease in childhood; it can be a primary or a secondary neoplasm. The latter is the most common: in this case, the breast is involved as a metastatic site of different cancer originated elsewhere, such as rhabdomyosarcoma, neuroblastoma, lymphoma, or leukemia. Primary tumors, instead, arise from the breast, and in childhood, there are occasional reports about carcinoma [1], rhabdomyosarcoma [2], and lymphoma [3].

Primary breast lymphoma (PBL) is an extremely rare non-Hodgkin lymphoma (NHL); it represents less than $3 \%$ of all extranodal NHL and its onset in childhood is exceptional [4]. The criteria that must be fulfilled for the PBL diagnosis were defined by Wiseman and Liao in

\footnotetext{
*Correspondence: diberuss@unict.it

${ }^{7}$ Pediatric Hematology and Oncology Unit - AOU Policlinico

"Rodolico-San Marco", University of Catania, Catania, Italy

Full list of author information is available at the end of the article
}

1972 [3]: (i) adequate pathological specimen with evidence of both mammary tissue and lymphomatous infiltrate, (ii) absence of concurrent metastatic disease (only the involvement of homolateral axillary nodes is acceptable), (iii) absence of a previous diagnosis of extramammary lymphoma.

We report a case of PBL in a 15-year-old girl, who was treated with chemotherapy plus rituximab. A review of the pediatric literature on this topic was conducted thereafter.

\section{Case presentation}

A 15-year-old girl presented with a palpable mass in her right breast, which she has had for 2 months; during this time, she noticed that the lump had not increased in size. She did not have systemic symptoms or a history of weight loss. During the physical examination, two solid and painless masses were appreciated in the upper-outer 


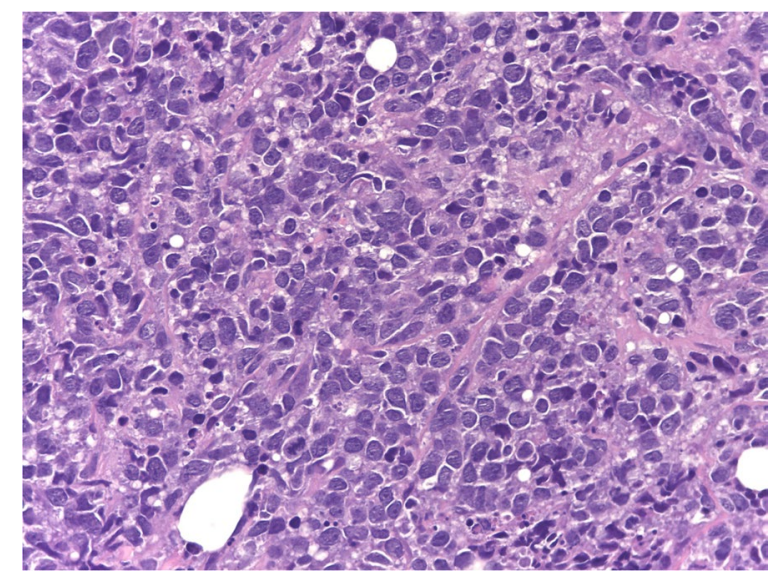

Fig. 1 Hematoxylin-eosin staining

and the central-low quadrants; the skin overlying the lesions was completely normal and there were no palpable lymph nodes. Blood count, liver and kidney function tests, erythrocyte sedimentation rate (ESR), lactate dehydrogenase (LDH), and uric acid blood levels were in the normal range. Ultrasound (US) showed a $6 \mathrm{~cm}$ hypervascular mass with indistinct margins in the upperouter quadrant and other two smaller masses (diameter $1.9 \mathrm{~cm}$ and $2.1 \mathrm{~cm}$, respectively), probably connected to the largest one, in the central-low portion; moreover, two enlarged homolateral axillary lymph nodes (maximal diameter $1.7 \mathrm{~cm}$ ) were identified. On breast magnetic resonance imaging (MRI), a $6.5 \mathrm{~cm}$ single and irregular mass with intense contrast enhancement and three suspected axillary nodes (maximal diameter $1.5 \mathrm{~cm}$ ) were described. US-guided needle biopsy of the right breast lesion was performed; analysis was carried out with a Leica microscope (dm2000 led, Objective: x63), Leica ICC50HD camera and Leica Acquire software for Macbook pro

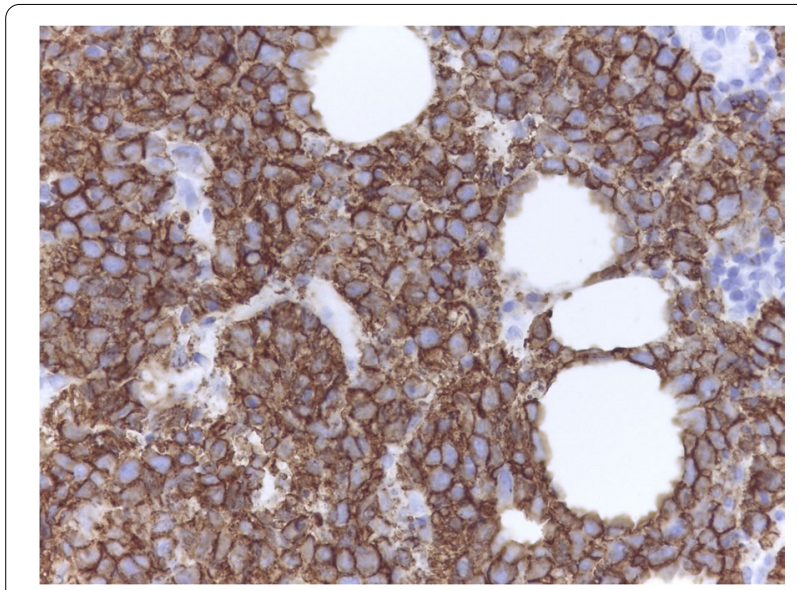

Fig. 2 CD20 staining
16' 2,6 GHz 6-Core Intel Core i7; histologic examination (Figs. 1 and 2) showed a diffuse large B-cell lymphoma, not otherwise specified (DLBCL, nos), CD19+, CD20+, of germinal center origin according to immunohistochemical algorithms (CD10+, BCL6+, IRF4/MUM1+, FoxP1+, LMO2+, HGAL+), with high proliferation index (MIB-1 80\%). A high expression of c-MYC protein was found (70\%); however, fluorescence in situ hybridization (FISH) analysis was negative for MYC translocation (Vysis break apart and IGH/MYC dual fusion translocation probes) as well as for BCL2 and BCL6 translocations (Break apart translocation probes), excluding a highgrade B-cell lymphoma with double hit. Finally, no evidence of Epstein-Barr virus (EBV) was found with in situ hybridization for the Epstein-Barr virus-encoded small RNAs (EBERs). The staging was completed with bone marrow aspirate, lumbar puncture, brain MRI, neck-thorax-abdomen computerized tomography (CT) scan, and whole-body positron emission tomography (PET)-CT scan (Fig. 3 A); a high fluorodeoxyglucose (FDG) uptake with a maximum standardized uptake value (SUVmax) of 11.5 was evidenced in the right breast. No other organ involvement was ascertained. According to St. Jude staging [5] and the new revised International Pediatric NonHodgkin Lymphoma Staging System (IPNHLSS) [6], the stage was IIE (single extranodal tumor with regional node involvement). The girl received intensive combination chemotherapy according to the AIEOP LNH-97 trial (risk group 3) [7] plus rituximab (Table 1). After the second block of chemotherapy, breast MRI and wholebody PET-CT scan showed a complete radiologic and metabolic response (Fig. 3B). These examinations were

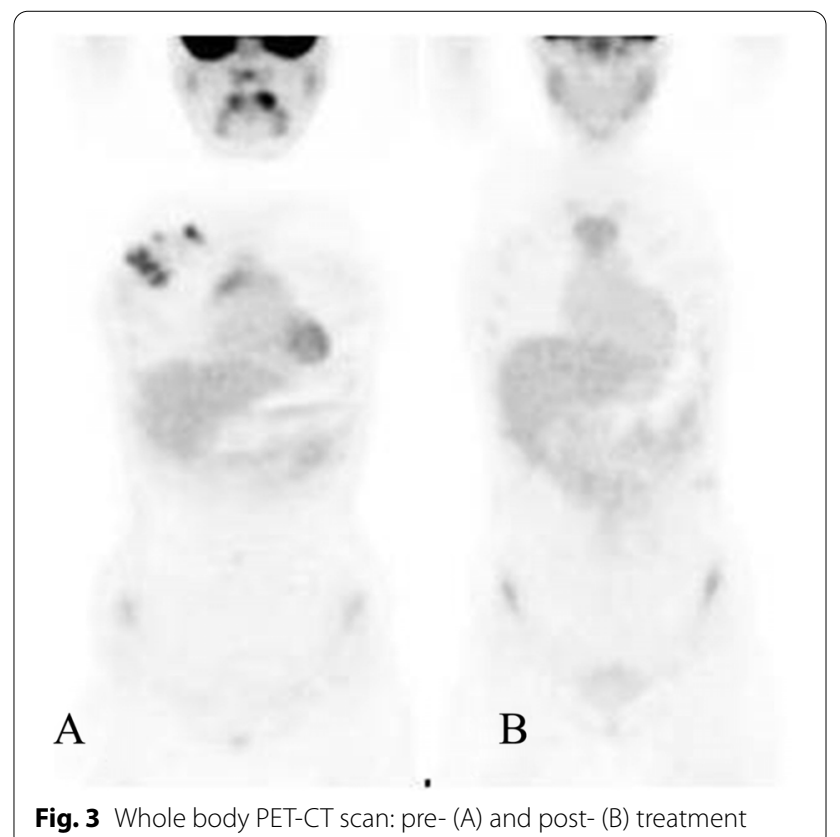


Table 1 Therapy courses according to AIEOP LNH-97 protocol plus rituximab. According to the treatment risk group (R3), patients received the following chemotherapy cycles: prephase, $A A, B B, C C, A A, B B$

\begin{tabular}{|c|c|c|c|c|c|c|c|}
\hline \multirow[b]{2}{*}{ Drug } & \multirow[b]{2}{*}{ Dose } & \multicolumn{6}{|c|}{ Days } \\
\hline & & 0 & +1 & +2 & +3 & +4 & +5 \\
\hline \multicolumn{8}{|l|}{ Prephase } \\
\hline Dexamethasone orally/I ${ }^{\mathrm{a}}$ & $\mathrm{mg} / \mathrm{sqm}$ & & 5 & 5 & 10 & 10 & 10 \\
\hline Cyclophosphamide IV (1 h) & $200 \mathrm{mg} / \mathrm{sqm} /$ day & & $x$ & $x$ & & & \\
\hline MTX+ARA-C+PDN IT & $12 \mathrm{mg}+30 \mathrm{mg}+10 \mathrm{mg}$ & & $x$ & & & & \\
\hline \multicolumn{8}{|l|}{ Cycle AA } \\
\hline RituximabIV & $375 \mathrm{mg} / \mathrm{sgm}$ & $x^{f}$ & & & & & \\
\hline Dexamethasone orally/IV ${ }^{\mathrm{a}}$ & $10 \mathrm{mg} / \mathrm{sgm}$ & & $x$ & $x$ & $x$ & $x$ & $x$ \\
\hline Vincristine IV $^{c}$ & $1.5 \mathrm{mg} / \mathrm{sqm}$ & & $x$ & & & & \\
\hline Methotrexate IV ${ }^{d}$ & $5 \mathrm{~g} / \mathrm{sqm}$ & & $x$ & & & & \\
\hline Ifosfamide IV (1 h) & $800 \mathrm{mg} / \mathrm{sgm}$ & & $x$ & $\mathrm{x}$ & $x$ & $x$ & $x$ \\
\hline Etoposide IV (2 h) & $100 \mathrm{mg} / \mathrm{sqm}$ & & & & & $x$ & $x$ \\
\hline Cytarabine IV (1 h) & $150 \mathrm{mg} / \mathrm{sqm}$ & & & & & $x-x^{e}$ & $x-x^{e}$ \\
\hline MTX+ARA-C+PDN IT & $12 \mathrm{mg}+30 \mathrm{mg}+10 \mathrm{mg}$ & & $x$ & & & & \\
\hline \multicolumn{8}{|l|}{ Cycle BB } \\
\hline Rituximab IV & $375 \mathrm{mg} / \mathrm{sgm}$ & $x$ & & & & & \\
\hline Dexamethasone orally/V ${ }^{\mathrm{a}}$ & $10 \mathrm{mg} / \mathrm{sgm}$ & & $x$ & $\mathrm{x}$ & $x$ & $x$ & $x$ \\
\hline Vincristine IV ${ }^{c}$ & $1.5 \mathrm{mg} / \mathrm{sgm}$ & & $x$ & & & & \\
\hline Methotrexate IV $^{d}$ & $5 \mathrm{~g} / \mathrm{sgm}$ & & $x$ & & & & \\
\hline Cyclophosphamide IV (1 h) & $200 \mathrm{mg} / \mathrm{sqm} / \mathrm{day}$ & & $x$ & $x$ & $x$ & $x$ & $x$ \\
\hline Doxorubicin IV (4 h) & $25 \mathrm{mg} / \mathrm{sqm}$ & & & & & $x$ & $x$ \\
\hline MTX+ARA-C+PDN IT & $12 \mathrm{mg}+30 \mathrm{mg}+10 \mathrm{mg}$ & & $x$ & & & & \\
\hline \multicolumn{8}{|l|}{ Cycle CC } \\
\hline RituximabIV & $375 \mathrm{mg} / \mathrm{sgm}$ & $x$ & & & & & \\
\hline Dexamethasone orally/I ${ }^{\mathrm{a}}$ & $20 \mathrm{mg} / \mathrm{sgm}$ & & $x$ & $\mathrm{x}$ & $x$ & $x$ & $x$ \\
\hline Vindesine IV ${ }^{c}$ & $3 \mathrm{mg} / \mathrm{sqm}$ & & $\mathrm{x}$ & & & & \\
\hline Cytarabine IV (3 h) & $3 \mathrm{~g} / \mathrm{sqm}$ & & $x-x^{e}$ & $x-x^{e}$ & & & \\
\hline Etoposide IV (2 h) & $100 \mathrm{mg} / \mathrm{sam}$ & & & & & $x$ & $x$ \\
\hline$M t x+A R A-C+P D N I T$ & $12 \mathrm{mg}+30 \mathrm{mg}+10 \mathrm{mg}$ & & $x$ & & & & \\
\hline
\end{tabular}

Abbreviations: MTX: methotrexate; ARA-C: cytarabine; PDN: prednisolone; IV: intravenously; h: hours; IT: intrathecal; CNS: central nervous system; sqm: square meters ${ }^{\text {a }}$ subdivided in 3 doses

${ }^{b}$ Dose of IT chemotherapy was age-adjusted for children less than 3 years. In courses AA and BB, IT therapy was administered $2 \mathrm{~h}$ after beginning of MTX IV

' Maximum dose was $2 \mathrm{mg}$

d $10 \%$ of MTX dose was given in $0.5 \mathrm{~h}, 90 \%$ of dose over $23.5 \mathrm{~h}$. L-leucovorin rescue IV was $15 \mathrm{mg} / \mathrm{sqm}$ at $\mathrm{h} 42,7.5 \mathrm{mg} / \mathrm{sqm}$ at $\mathrm{h} 48$, and 54 after beginning of MTX

e Doses were $12 \mathrm{~h}$ apart

${ }^{f}$ For the first course AA, rituximab infusion on day 0 corresponded to day 5 of prephase

repeated at the end of the treatment, confirming the disappearance of any lesions. The total duration of chemotherapy was approximately 3 months and the girl is alive without any evidence of disease after 20 months from the end of treatment.

\section{Discussion and conclusion}

PBL is a rare form of extranodal lymphoma, affecting females in almost all cases. It is much more common in adulthood where it is difficult to distinguish clinically from breast carcinoma because both neoplasms typically present with a painless breast mass; in adults, the right breast is more involved than the left one and the most common histology is DLBCL [4]. A rare histologic type, the anaplastic large cell lymphoma (ALCL), predominates in women with breast implants [8].

PBL is an exceptional breast malignancy in the pediatric age; in literature, there are 11 case reports on this topic (Table 2) [9-19]. Although in other studies [20-25] some PBL patients aged from 15 years were reported, it was not possible to include these children in our review because no detailed information was presented. From 
the analysis of these 12 well-described pediatric patients (Table 3), it can be deduced that PBL mainly affects female adolescents (median and mean age 14.5 and 14.2 respectively) with only one 11-year-old boy; as in adulthood, there is a slight predominance of the right breast (6 out of 10 patients for whom the data are available), with only 1 girl showing bilateral involvement [15].

US with color-Doppler is frequently the first imaging technique, being not invasive and able to distinguish benign from malignant breast lesions in the majority of cases; on US, malignancies are typically hypoechoic masses with indistinct margins, irregular shape, and intense vascularization [26]. On MRI, PBL is characterized by hypointensity or isointensity at T1-weighted imaging and by hyperintensity at T2-weighted imaging, with homogenous or heterogeneous enhancement [27]. PET-CT, highly sensitive and specific in the tumor staging and the evaluation of treatment response, can show unifocal, multifocal, or diffuse high FDG uptake [28]. In agreement with the criteria proposed by Wiseman and Liao [3], PBL without axillary nodes involvement is classified as stage IE and, in case of loco-regional node metastases, as stage IIE; among the 9 patients in whom the stage is reported, there are 4 stage IE and 5 stage IIE. Histologic subtypes are available in 11 patients: 4 ALCL anaplastic lymphoma kinase (ALK) positive, 3 lymphoblastic lymphomas, 1 Burkitt lymphoma, 2 DLBCL, and 1 B-cell NHL not specified. This seems to be in discordance with adulthood where DLCBL is the predominant subtype (about $70 \%$ of all patients) [23].

As regards the treatment, different therapeutic approaches were used: 7 received chemotherapy, 3 patients underwent breast surgery only, and in 2 patients radiotherapy was added to surgery or chemotherapy. Currently, surgery is not considered a therapeutic choice. A large meta-analysis on patients with PBL aged from 17 to 95 years [23] showed that mastectomy offers no benefit in terms of event-free survival (EFS) and overall survival (OS). The current standard therapy for children affected by Burkitt lymphoma or DLBCL consists of chemotherapy tailored according to stage, LDH value, and disease dissemination; furthermore, the outcome of these patients has been recently improved by the addition of rituximab [29,30], an anti-CD20 monoclonal antibody already used in the treatment of adult primary breast DLBCL [31]. Our girl is the first PBL pediatric patient to be treated with polychemotherapy plus rituximab, probably because most of the patients analyzed in the present review were in the pre-rituximab era.

In our review, 8 children showed complete response to treatment, 3 girls ( 2 with ALCL) died for progression of disease, and in 1 patient the outcome was not specified; none of the analyzed clinical data, such as tumor size, unilateral or bilateral involvement, and disease stage seems to be associated with an unfavorable outcome. In adult patients, controversial results have been found: in Wong et al. [25], who evaluated 26 adult patients with primary breast NHL, the only significant prognostic factor for survival was the Ann Arbor stage; according to $\mathrm{Hu}$ et al. [22], who collected data on 108 patients with primary breast DLBCL aged between 16 and 85 years, tumor size larger than $5 \mathrm{~cm}$ and regional node involvement were not associated with significant changes in EFS or OS, while according to the meta-analysis of Jennings et al. [23] on 465 patients with PBL (mean age 54 years), nodal status was the best predictor of survival. Furthermore, it

Table 2 Main features of pediatric PBL patients reported in the literature and our case

\begin{tabular}{|c|c|c|c|c|c|c|c|}
\hline Reference & Age/Sex & Side & Size $(\mathrm{cm})$ & Stage & Histology & Treatment & Outcome (from onset) \\
\hline Dixon et al. 1987 [9] & $17 y / F$ & NA & 2 & NA & NHL unclassified & Surgery + RT & CR, 25 years \\
\hline Boothroyd et al. 1994 [10] & $11 \mathrm{y} / \mathrm{F}$ & Right & NA & NA & B-cell NHL & $\mathrm{CT}$ & CR, 36 months \\
\hline Rogers et al. 1994 [11] & $14 \mathrm{y} / \mathrm{F}$ & NA & $8 \times 7$ & $\| \mathrm{E}$ & $\mathrm{LBL}$ & $\mathrm{CT}$ & $C R$ \\
\hline Aguilera et al. 2000 [12] & $13 y / F$ & Left & $6 \times 6$ & IE & $\mathrm{ALCL} \mathrm{ALK+}$ & Surgery & Dead \\
\hline Barista et al. 2000 [13] & $17 y / F$ & Right & NA & $\| \mathrm{E}$ & DLBCL & $\mathrm{CHOP}+\mathrm{RT}$ & CR, 57 months \\
\hline Abdullah et al. 2004 [14] & $15 y / F$ & Left & 5 & IE & $\mathrm{ALCL} \mathrm{ALK}+$ & $\begin{array}{l}\text { CT (cyclophosphamide, predniso- } \\
\text { lone) }\end{array}$ & CR, 22 years \\
\hline Lingohr et al. 2009 [15] & $12 \mathrm{y} / \mathrm{F}$ & Bilateral & NA & NA & $\mathrm{BL}$ & Surgery & Dead \\
\hline Daneshbod et al. 2010 [16] & $16 y / F$ & Right & NA & $\| \mathrm{E}$ & $\mathrm{ALCL} \mathrm{ALK+}$ & $\mathrm{CHOP}$ & Dead \\
\hline Ishizuka et al. 2020 [17] & $14 \mathrm{y} / \mathrm{F}$ & Right & 4 & IE & $\mathrm{LBL}$ & CT (ALL, not specified trial) & CR, 8 months \\
\hline Charfi et al. 2020 [18] & $16 y / F$ & Left & NA & $\| \mathrm{E}$ & ALCL ALK + & $\begin{array}{l}\text { СТ (doxorubicin, bleomycin, vincris- } \\
\text { tine, dacarbazine) }\end{array}$ & CR, 24 months \\
\hline Oral et al. 2021 [19] & $11 \mathrm{y} / \mathrm{M}$ & Right & $3.5 \times 1.7$ & IE & $\mathrm{LBL}$ & Surgery & NA \\
\hline Our case & $15 y / F$ & Right & 6.5 & $\| \mathrm{E}$ & DLBCL & CT (AIEOP LNH-97 trial) & $C R, 20$ months \\
\hline
\end{tabular}

Abbreviations: years; NA: not available; RT: radiotherapy; CR: complete remission; LBL: lymphoblastic lymphoma; CT: chemotherapy; ALCL: anaplastic large cell lymphoma; ALK: anaplastic lymphoma kinase; DLBCL; diffuse large B-cell lymphoma; CHOP: cyclophosphamide + doxorubicin + vincristine + prednisone; BL: Burkitt lymphoma; ALL: acute lymphoblastic leukemia 
Table 3 Main features of pediatric PBL patients sorted by frequency

\begin{tabular}{|c|c|c|}
\hline $\mathbf{N}^{\circ}$ & 12 & Frequency (\%) \\
\hline \multicolumn{3}{|l|}{ Age (years) } \\
\hline Median/Mean & $14.5 / 14.2$ & - \\
\hline \multicolumn{3}{|l|}{ Sex } \\
\hline Female & 11 & 91.7 \\
\hline Male & 1 & 8.3 \\
\hline \multicolumn{3}{|l|}{ Side } \\
\hline Unilateral & 9 & 75 \\
\hline Bilateral & 1 & 8.3 \\
\hline Unknown & 2 & 16.7 \\
\hline \multicolumn{3}{|l|}{ Size } \\
\hline$\leq 5 \mathrm{~cm}$ & 4 & 33.3 \\
\hline$>5 \mathrm{~cm}$ & 3 & 25 \\
\hline Unknown & 5 & 41.7 \\
\hline \multicolumn{3}{|l|}{ Histology } \\
\hline $\mathrm{ALCL}$ & 4 & 33.3 \\
\hline LBL & 3 & 25 \\
\hline DLBCL & 2 & 16.7 \\
\hline $\mathrm{BL}$ & 1 & 8.3 \\
\hline B-cell NHL & 1 & 8.3 \\
\hline NHL unclassified & 1 & 8.3 \\
\hline \multicolumn{3}{|l|}{ Stage } \\
\hline IE & 4 & 33.3 \\
\hline$\| \mathrm{E}$ & 5 & 41.7 \\
\hline Unknown & 3 & 25 \\
\hline \multicolumn{3}{|l|}{ Local treatment } \\
\hline Surgery only & 3 & 25 \\
\hline Surgery + RT & 1 & 8.3 \\
\hline \multicolumn{3}{|l|}{ Chemotherapy } \\
\hline CT only & 7 & 58.3 \\
\hline$C T+R T$ & 1 & 8.3 \\
\hline \multicolumn{3}{|l|}{ Outcome } \\
\hline$C R$ & 8 & 66.6 \\
\hline Dead & 3 & 25 \\
\hline Unknown & 1 & 8.3 \\
\hline
\end{tabular}

Abbreviations: ALCL: anaplastic large cell lymphoma; DLBCL: diffuse large B-cell lymphoma; BL: Burkitt lymphoma; LBL: lymphoblastic lymphoma; LNH: non-Hodgkin lymphoma; $\mathrm{CT}$ : chemotherapy; RT: radiotherapy; CR: complete remission

has not yet been investigated whether the different histological subtypes are correlated to prognosis.

In conclusion, PBL is a rare and poorly investigated type of NHL in childhood, with most of the information resulting from studies performed on adults. In pediatric patients, it mainly affects female adolescents and the most common presentation is a unilateral breast mass. Different lymphoma subtypes have been described and, unlike adult patients, DLBCL seems not to be the most frequent histology. No prognostic factors have been clearly determined and different therapeutic approaches have been used, from chemotherapy to local treatment with surgery and/or radiotherapy. Our case is unique because it is the first pediatric primary breast DLBCL patient treated with chemotherapy plus rituximab. Further pediatric researches are needed in order not only to verify the efficacy of rituximab and improve treatment strategies but also to identify specific molecular features and prognostic factors.

\section{Acknowledgements}

The Parents' Association S.P.I.A (Sicilian Primary Immunodeficiency Association) is acknowledged for supporting the activity of the Pediatric Onco-Hematology Unit of A.R.N.A.S. Ospedali Civico, Di Cristina e Benfratelli.

\section{Authors' contributions}

Conceptualization, G.A.R. and P.F.; data curation, A.G., S.I., A.Z., A.T, and C.M.; formal analysis, P.D., G.A.R., and P.F; methodology, C.E., G.A.R., and P.F; project administration, G.R. and P.F.; resources, G.R.; software, C.E. and E.C.; supervision, G.A.R., M.M., M.P., L.R., and P.F; validation, G.A.R. and P.F.; visualization, S.I, A.Z, G.A.R., and P.F; writing - original draft, G.A.R.; writing - review and editing, G.R., M.P., L.R., and P.F. All authors have read and agreed to the published version of the manuscript.

\section{Funding}

This research received no external funding; the APC was funded by AOU Policlinico Rodolico-San Marco, Progetto Obiettivo PSN Anno 2016.

\section{Availability of data and materials}

The data and materials of this case report are available from the corresponding author upon reasonable request.

\section{Declarations}

\section{Ethics approval and consent to participate}

Ethics approval was granted by the internal Institutional Review Board, ARNAS Ospedali Civico, G. Di Cristina, Palermo, after consideration by the heads of Pediatric Hemato-Oncology and Radiology Units. Written informed consent was obtained from the parents of the patient.

\section{Consent for publication}

Written informed consent was obtained from the patient's parents for publication of this case report and the accompanying images.

\section{Competing interests}

The authors declare no conflict of interests.

\section{Author details}

${ }^{1}$ Department of Health Promotion, Mother and Child Care, Internal Medicine and Medical Specialties "G. D'Alessandro", University of Palermo, Palermo, Italy. ${ }^{2}$ Clinic of Pediatric Hemato-Oncology, Department of Women's and Children's Health, University of Padova, Padova, Italy. ${ }^{3}$ Institute of Pediatric Research - Fondazione Città della Speranza, Padova, Italy. ${ }^{4}$ Department of Pediatric Hemato-Oncology, ARNAS Ospedali Civico, G. Di Cristina, Palermo, Italy. ${ }^{5}$ Nuclear Medicine Unit, Ospedali Riuniti Villa Sofia-Cervello, Palermo, Italy. ${ }^{6}$ Department of Pathology, San Bortolo Hospital, Vicenza, Italy. ${ }^{7}$ Pediatric Hematology and Oncology Unit - AOU Policlinico "Rodolico-San Marco", University of Catania, Catania, Italy. ${ }^{8}$ AYA Oncology and Pediatric Radiotherapy Unit, CRO - Centro di Riferimento Oncologico di Aviano, IRCCS, Aviano, Italy. ${ }^{9}$ Radiology Unit, Radiology Department, A.R.N.A.S. Ospedali Civico, Di Cristina e Benfratelli, Palermo, Italy.

Received: 22 June 2021 Accepted: 13 November 2021

Published online: 30 November 2021 


\section{References}

1. Murphy JJ, Morzaria S, Gow KW, Magee JF. Breast cancer in a 6-year-old child. J Pediatr Surg. 2000;35(5):765-7.

2. Mance M, Smuđ-Orehovec S, Vrbanović-Mijatović V, Mijatović D Primary alveolar rhabdomyosarcoma of the breast in a 17-year-old girl. J Oncol Pract. 2020;16(2):93-5.

3. Wiseman C, Liao KT. Primary lymphoma of the breast. Cancer. 1972;29:1705-12.

4. Cheah CY, Campbell BA, Seymour JF. Primary breast lymphoma. Cancer Treat Rev. 2014;40(8):900-8.

5. Murphy SB. Classification, staging and end results of treatment of childhood non-Hodgkin lymphomas: dissimilarities from lymphomas in adults. Semin Oncol. 1980;7:332-9.

6. Rosolen A, Perkins SL, Pinkerton CR, Guillerman RP, Sandlund JT, Patte C, Reiter A, Cairo MS. Revised international pediatric non-Hodgkin lymphoma staging system. J Clin Oncol. 2015;33:2112-8.

7. Pillon M, Mussolin L, Carraro E, Conter V, Aricò M, Vinti L, Garaventa A, Piglione M, Buffardi S, Sala A, Santoro N, Lo Nigro L, Mura R, Tondo A, Casale F, Farruggia P, Pierani P, Cesaro S, D’Amore ES, Basso G. Detection of prognostic factors in children and adolescents with Burkitt and diffuse large B-cell lymphoma treated with the AIEOP LNH-97 protocol. Brit J Haematol. 2016;175:467-75.

8. Thompson PA, Prince HM. Breast implant-associated anaplastic large cel lymphoma: a systematic review of the literature and mini-meta analysis. Curr Hematol Malignancy Rep. 2013;8(3):196-210.

9. Dixon JM, Lumsden AB, Krajewski A, Elton RA, Anderson TJ. Primary lymphoma of the breast. Br J Surg. 1987:74(3):214-6.

10. Boothroyd A, Carty H. Breast masses in childhood and adolescence. A presentation of 17 cases and a review of the literature. Pediatr Radiol. 1994;24(2):81-4.

11. Rogers DA, Lobe TE, Rao BN, Fleming ID, Kurt PS, Pratt CB, Pappo AS. Breast malignancy in children. J Pediatr Surg. 1994;29:48-51.

12. Aguilera NS, Tavassoli FA, Chu WS, Abbondanzo SL. T-cell lymphoma presenting in the breast: a histologic, immunophenotypic and molecular genetic study of four cases. Modern Pathol. 2000;13(6):599-605.

13. Barișta I, Baltali E, Tekuzman G, Kars A, Ruacan S, Ozisik Y, Guler N, Gullu IH, Atahan IL, Firat D. Primary breast lymphomas - a retrospective analysis of twelve cases. Acta Oncol. 2000;39(2):135-9.

14. Abdullah N, Behranwala KA, Wotherspoon A, Gui GP. Adolescent breast lymphoma - apparently aggressive presentation with favourable outcome. J Postgrad Med. 2004;50(3):236-7.

15. Lingohr P, Eidt S, Rheinwalt KP. A 12-year-old girl presenting with bilateral gigantic Burkitt's lymphoma of the breast. Arch Gynecol Obstet. 2009;279(5):743-6.

16. Daneshbod Y, Oryan A, Khojasteh HN, Rasekhi A, Ahmadi N, Mohammadianpanah M. Primary ALK-positive anaplastic large cell lymphoma of the breast: a case report and review of the literature. J Pediatr Hematol Oncol. 2010;32(2):75-8.

17. Ishizuka Y, Horimoto $Y$, Fujimura J, Ogata K, Murakami F, Onagi H. Primary breast non-Hodgkin's lymphoma in a 14-year-old girl: a case report. Surg Case Rep. 2020;6:87.

18. Charfi L, Houcine Y, Yahyaoui Y, Sahraoui G, Chraiet N, Mrad K, Doghri R. Primary breast Anaplasic Lymphoma Kinase-positive anaplastic lymphoma in an adolescent. Breast J. 2020;26(10):2068-9.

19. Oral H, Turkyilmaz Z, Arslan Kahraman Di, Kaya C, Karabulut R, Tartık A, Sönmez K. B-cell lymphoblastic lymphoma of unilateral primary breast mass in a boy aged 11 years. Breast J. 2021;27(3):271-2.

20. el-Ghazawy IM, Singletary SE. Surgical management of primary lymphoma of the breast. Ann Surg. 1991;214(6):724-6.

21. Hosein PJ, Maragulia JC, Salzberg MP, Press OW, Habermann TM, Vose JM, Bast M, Advani RH, Tibshirani R, Evens AM, Islam N, Leonard JP, Martin P, Zelenetz AD, Lossos IS. A multicentre study of primary breast diffuse large B-cell lymphoma in the rituximab era. Br J Haematol. 2014;165:358-63.

22. Hu S, Song Y, Sun $X$, Su L, Zhang W. Primary breast diffuse large B-cell lymphoma in the rituximab era: Therapeutic strategies and patterns of failure. Cancer Sci. 2018;109:3943-52.

23. Jennings WC, Baker RS, Murray SS, Howard CA, Parker DE, Peabody LF, Vice HM, Sheehan WW, Broughan TA. Primary breast lymphoma: the role of mastectomy and the importance of lymph node status. Ann Surg. 2007;245(5):784-9.
24. Ryan G, Martinelli G, Kuper-Hommel M, Tsang R, Pruneri G, Yuen K, Roos D, Lennard A, Devizzi L, Crabb S, Hossfeld D, Pratt G, Dell'Olio M, Choo SP, Bociek RG, Radford J, Lade S, Gianni AM, Zucca E, Cavalli F, Seymour JF, International Extranodal Lymphoma Study Group. Primary diffuse large B-cell lymphoma of the breast: prognostic factors and outcomes of a study by the International Extranodal Lymphoma Study Group. Ann Oncol. 2008;19(2):233-41.

25. Wong WW, Schild SE, Halyard M, Schomberg PJ. Primary non-Hodgkin lymphoma of the breast: The Mayo Clinic Experience. J Surg Oncol. 2002;80(1):19-25; discussion 26.

26. Gao Y, Saksena MA, Brachtel EF, Deborah C, Rafferty EA. How to approach breast lesions in children and adolescents. Eur J Radiol. 2015;84(7):1350-64

27. Raj SD, Shurafa M, Shah Z, Raj KM, Fishman MDC, Dialani VM. Primary and secondary breast lymphoma: clinical, pathologic and multimodality imaging review. Radiographics. 2019;39(3):610-25.

28. Dong A, Wang Y, Lu J, Zuo C. Spectrum of the breast lesions with increased 18F-FDG uptake on PET/CT. Clin Nuclear Med. 2016;41(7):543-57.

29. Minard-Colin V, Auperin A, Pillon M, Burke A, Anderson JR, Barkauskas DA, Wheatley K, Delgado R, Alexander S, Uyttebroeck A, Bollard C, Zsiros J, Csoka M, Goma G, Tulard A, Patte C, Gross TG. Results of the randomized Intergroup trial Inter-B-NHL Ritux 2010 for children and adolescents with high-risk B-cell non-Hodgkin lymphoma (B-NHL) and mature acute leukemia (B-AL): Evaluation of rituximab (R) efficacy in addition to standard LMB chemotherapy (CT) regimen. J Clin Oncol. 2016:34(15 suppl):10507-10507.

30. Mussolin L, Lovisa F, Gallingani I, Cavallaro E, Carraro E, Damanti CC, Vinti L, Sala A, Micalizzi C, Santoro N, Piglione M, Cellini M, Buffardi S, Buldini B, D'Amore E, Biffi A, Pillon M. Minimal residual disease analysis in childhood mature B-cell leukaemia/lymphoma treated with AIEOP LNH-97 protocol with/without anti-CD20 administration. Br J Haematol. 2020,189(3):e108-e111.

31. Aviv A, Tadmor T, Polliack A. Primary diffuse large B-cell lymphoma of the breast: looking at pathogenesis, clinical issues and therapeutic options. Ann Oncol. 2013:24(9):2236-44.

\section{Publisher's Note}

Springer Nature remains neutral with regard to jurisdictional claims in published maps and institutional affiliations.

Ready to submit your research? Choose BMC and benefit from

- fast, convenient online submission

- thorough peer review by experienced researchers in your field

- rapid publication on acceptance

- support for research data, including large and complex data types

- gold Open Access which fosters wider collaboration and increased citations

- maximum visibility for your research: over 100M website views per year

At BMC, research is always in progress.

Learn more biomedcentral.com/submissions 